\title{
THE MIOCENE CALCAREOUS NANNOFOSSILS FROM BISTRIȚA AREA (TRANSYLVANIA, ROMANIA)
}

\author{
CARMEN CHIRA ${ }^{1}$, ANA-MARIA VULC ${ }^{1}$
}

\begin{abstract}
The Middle Miocene (Badenian, Sarmatian and Pannonian) deposits from the region of Bistrița, between the localities: Susenii Bârgăului, Livezile, Bistrița, Sărata, Sărățel, Budacu de Sus (Transylvanian Basin) have been analysed from the nannofloral point of view. The nannofossils are relatively scarce, excepting the ones related to Lower Badenian deposits. Only the fossil index for NN5 Zone - Sphenolithus heteromorphus, and for NN6 Zone - Discoaster exilis have been identified.
\end{abstract}

Keywords: Middle Miocene, Transylvania, calcareous nannofossils.

\section{INTRODUCTION}

The Middle Miocene deposits are represented, in the region of Bistrița, (located between Josenii Bârgăului, Livezile, Bistrița, Sărata, Sărătel and Budacu de Sus localities) by Badenian, Sarmatian and Pannonian sediments (Fig. 1). The investigation of these deposits were focussed, so far, mainly on foraminifera, ostracods, a. o. groups of organisms.

The prevoius geological studies in the region of Bistrița belong to Hauer \& Stache (1863), Koch (1900), Ciocîrdel (1953), Pătruț (1952), and more recently to Petrescu \& Chintăuan (1987), Chintăuan (1994), Chira (1999; 2000; 2001), Vulc (2002; 2003), a.o.

The purpose of this paper is to present the results of our nannofloral analysis carried out on the Middle Miocene sediments from the Bistrița region.

\section{GEOLOGICAL SETTING}

The oldest Middle Miocene formations in the Bistrita region (Lower Badenian in age) are located in the western and north-western part of the studied area (between Josenii Bârgăului, Herina, Sărata and Sărățel), and belong to the Dej Formation. The Middle Badenian sediments belong to Ocna Dejului and Mires Formation. The deposits of Mireş Formation and Iris Formation (Lower Sarmatian) are outcropping in the south-eastern part of Bistrița region (Bistrița - Cărămidărie quarry, Livezile, Budacu de Sus).

The Dej Formation consists of marls, and tuffs (the Dej Tuff), the later being well developed in the Cireşului Hill - Josenii Bârgăului area.

The Middle Badenian (= Wieliczkian) sediments are represented by salt deposits in Sărata, Sărățel and Herina areas. To remark that this type of deposits, of chemical precipitation, from the Transylvanian Basin, located on the top of Dej Formation, were previously included by Popescu (1972) in the Mireş Formation,

\footnotetext{
1 "Babeş-Bolyai” University, Department of Geology, Str. Kogălniceanu 1, 3400 Cluj-Napoca, Romania.
} 
which contains "Ocna Dejului Member", the "radiolarian shales" and the "Spirialis marls". Mészáros (1991) denominated the chemical precipitation deposits as "Ocna Dejului Beds". On the western border of the Transylvanian Basin, Filipescu (1996) described the gypsum deposits, occuring in Copăceni - Sănduleşti - Cheia area, as Cheia Formation (Middle Badenian). This lithostratigraphical unit is considered to be an equivalent of the "Ocna Dejului Member", established for the deeper salt facies, present in diapiric structures east from the border of the basin (Filipescu, 1996). In the most recent revision of the lithostratigraphic units from Transylvania (Filipescu, 2001), the salt-containing deposits of the Middle Badenian (Wieliczkian) (Late Langhian) formation was named Ocna Dejului Formation (according to Mészáros, 1991).

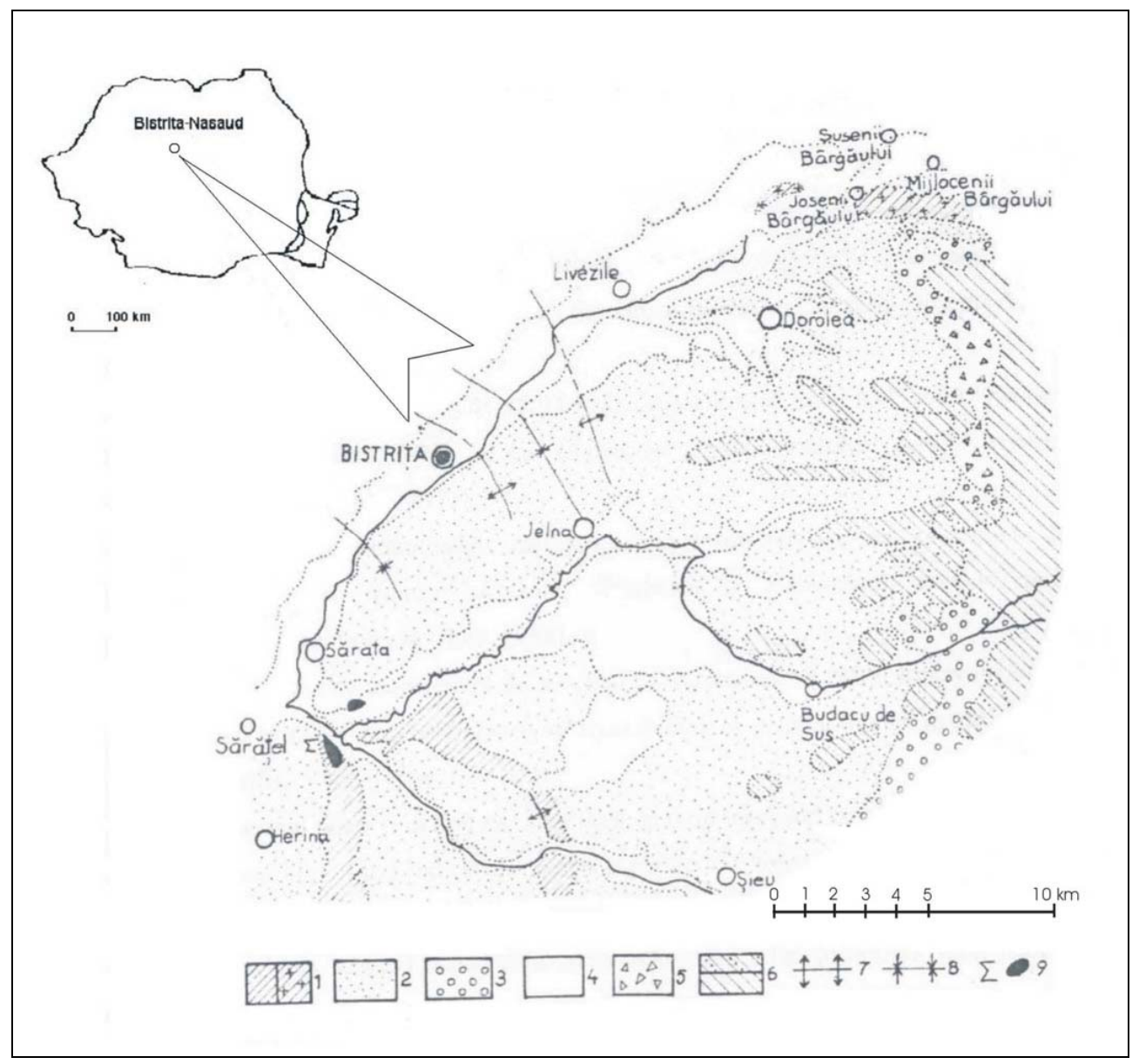

Fig. 1. Location map of the studied area (Bistrița - Năsăud county): Susenii Bârgăului, Livezile, Sărata, Sărățel, Budacu de Sus. Legend: 1. Badenian, 2. Sarmatian, 3. Pannonian, 4. Quaternary fluviatile deposits, 5. Quaternary colluvial - deluvial deposits, 6. Pannonian and Quaternary magmatic rocks, 7 - anticline, 8 - syncline, 9. Salt diapir (after the geological map 1:200.000 - Marinescu \& Peltz, 1967, with modifications). 
Mészáros et al. (1989), based on calcareous nannoplankton, considered the salt deposits from Turda area as belonging to the upper part of the NN5 Zone. In generally, the salt from the Transylvanian Basin was considered to be late Early Badenian in age.

The deposits of the Mireş Formation, overlying the salt formation and characterised, lithologically point of view by "radiolarian shales" and "Spirialis marls", are located in the neighborhood of Budacu de Sus - Budacu Valley.

The next lithostratigraphical unit is the Iris Formation, outcropping in Bistrița Cărămidărie quarry, and represented by marls and clays.

The Feleac Formation (investigated near Domneşti), overlying the Iris Formation, consists of sandstones and sands.

The Pannonian sediments, belonging to Lopadea Formation are present at Budacu de Sus and are represented by sands, sandstones, conglomerates and marls.

\section{MIDDLE MIOCENE CALCAREOUS NANNOFOSSILS ASSEM- BLAGES: GENERAL CONSIDERATIONS FOR THE TRANSYLVANIAN BASIN AND RESULTS FROM BISTRIȚA AREA}

\section{III.1. Material and methods}

Over 50 samples were taken to be analyzed nannofossil point of view, from the Dej, Ocna Dejului, Miriş, Iris, Feleac and Lopadea formations,.

The smear slides were studied under the light microscope, with magnification 1000. (1998).

The listed nannofossil species are indexed in Perch-Nielsen (1985) and Young

\section{III.2. Biostratigraphy}

The calcareous nannoplankton assemblages of Badenian age belong to NN5 Zone - with Sphenolithus heteromorphus and to NN6 Zone - with Discoaster exilis, according to the Standard Nannoplankton Zonation (Martini, 1971).

The Badenian nannoplankton bioevents from the Transylvanian Basin have been established by Mărunțeanu \& Chira (1998).

Concerning the calcareous nannofossils, some features were evidenced for the Badenian (Moravian, Wieliczkian, and Kossovian) of the Carpathian area from Romania (Mărunțeanu \& Chira, 1998):

- the lower boundary of the Badenian, corresponding to the beginning of NN5 Zone, cannot be correlated with the beginning of the Langhian, characterized by the upper part of NN4 Zone.

- the Moravian is characterized by the NN5 Zone assemblage, its lower boundary corresponding to the extinction of Helicosphaera ampliaperta and/or the first occurrence (FO) of Discoaster exilis.

- the Wieliczkian can be defined as the time interval beginning with the FO of Discoaster brouweri, being indicated by the upper part of NN5, and the lower part of NN6 zones. 
- the Kossovian covers most of the NN6 Zone, its upper boundary being marked by the extinction of Cyclicargolithus floridanus.

- the Badenian top was defined, in nannoplankton terms, by the NN7 Zone, by Müller (1974), Fuchs \& Stradner (1977), Rögl \& Müller (1976), Mészáros (1991) a. o.

NN5 Zone was defined by Bramlette \& Wilcoxon (1967), between the last occurrences of Helicosphaera ampliaperta and the last appearances of Sphenolithus heteromorphus.

The nannofossil content of Sphenolithus heteromorphus Zone (NN5) consists of Sphenolithus heteromorphus, Discoaster exilis, Discoaster musicus, Discoaster variabilis, Holodiscolithus macroporus, etc.

Discoaster brouweri, Helicosphaera wallichii and Sphenolithus abies have simultaneous first occurrences before the last appearance of Sphenolithus heteromorphus.

The Sphenolithus heteromorphus Zone can be correlated with the following foraminifera zones: Candorbulina glomerosa, and Candorbulina universal Globorotalia bykovae (defined by Popescu, 1970), characterizing the Early Badenian, then with the basis of Globigerina druryilGloborotalia transsylvanica (defined by Popescu \& Gheța, 1984), which indicates the debut of Middle Badenian.

\section{III.3. Nannofloral assemblages}

The Badenian sediments (the Dej Formation) from Cireşului Hill - Josenii Bârgăului have been considered to belong to the NN5 Nannofossil Zone (Tab. 1). To remark that in the studied area, the Dej Tuff, marking the beginning of the formation, is present.

The Discoaster exilis Zone (NN6) (Martini \& Worsley, 1970) includes the stratigraphic interval between the extinction of Sphenolithus heteromorphus and the first occurrence of Discoaster kugleri. Its upper boundary can also be approximated by the last appearances of Cyclicargolithus floridanus.

Its lower part is characterized by the explosive development of Discoaster brouweri and the presence of rare Triquetrorhabdulus rugosus.

The nannoplankton content, specific to the Discoaster exilis Zone, consists of Discoaster brouweri, Discoaster exilis, Discoaster variabilis, Helicosphaera wallichii, Sphenolithus abies, Triquetrorhabdulus rugosus, Syracolithus dalmaticus, Scapholithus fossilis, Helicosphaera walbersdorfensis etc., that occur at different stratigraphic levels.

The NN6 Zone can be correlated to Globigerina druryilGloborotalia transsylvanica and Velapertina foraminifera Zones, which characterize the Middle, and respectively the Late Badenian.

Based on detailed studies of the Badenian calcareous nannofossils of Romania, the subzones corresponding to the Wieliczkian (Mărunțeanu et al., 2000) have been established. This allowed the establishment of several bioevents that are very important for regional and worldwide biostratigraphic correlations. On their basis, the Sphenolithus heteromorphus - NN5 and Discoaster exilis - NN6 standard zones, which exclusively characterize Badenian nannoplankton assemblages, were subdivided into several subzones, as follows: Geminilithella rotula - NN5a, that defines the Moravian Substage; Helicosphaera wallichii - NN5b and Discoaster variabilis - NN6a, typical for Wielician Substage; Syracosphaera histrica - NN6b, Syracolithus dalmaticus NN6c and Calcidiscus pataecus - NN6d, which characterize the Kossovian Substage.

The Wieliczkian, (after Mărunțeanu et al., 2000), characterized by Helicosphaera wallichii - NN5b and Discoaster variabilis - NN6a subzones, can be correlated to the Uppermost Langhian, defined by the uppermost parts of the Eu-discoaster musicus 
Subzone (Theodoridis, 1984) or Helicosphaera walbersdorfensis/Sphenolithus heteromorphus Subzone (Fornaciari et al., 1996) and with the Lowermost Serravallian, defined by Helicosphaera walbersdorfensis and Helicosphaera stalis subzones (Theodoridis, 1984) or Sphenolithus heteromorphus/ Reticulofenestra pseudoumbilicus - MNN6a and Reticulofenestra pseudoumbilicus - MNN6b subzones (Fornaciari et al., 1996).

The Wieliczkian deposits with salt are present in the investigated area at Sărata and Sărățel (Tab.1).

In the opinion of Young (in Bown, 1998), the mentioned nannoplankton assemblages correspond to the intervals $\mathbf{C}$ partim and D partim. Interval C (NN45/CN3-4) was defined by the LO of Sphenolithus belemnos to LO of Sphenolithus heteromorphus. Sphenolithus heteromorphus is a distinctive and abundant species which characterizes this interval. This interval shows a rich diversity, including new species like Calcidiscus premacintyrei and Discoaster exilis. The most common species are: Cyclicargolithus floridanus, Coccolithus pelagicus, Calcidiscus spp., Sphenolithus moriformis, S. heteromorphus, Discoaster exilis, Helicosphaera carteri, Umbilicosphaera jafari, and U. rotula. Interval D was defined from the LO of Sphenolithus heteromorphus to FO of Catinaster (NN6-7/CN5a-b). This interval is of low diversity. Many species from the earlier assemblages are rare, such as: Cyclicargolithus floridanus, Sphenolithus heteromorphus, a.o. The most common species are considered to be: Reticulofenestra pseudoumbilicus, Coccolithus pelagicus, Calcidiscus leptoporus, Discoaster exilis, Helicosphaera carteri, Umbilicosphaera jafari, and U. rotula. Other species, e.g. Triquetrorhabdulus rugosus, which is less common, are considered to be more useful for biozonation purposes (Young in Bown, 1998).

According to Peryt (1997), the studied Middle Badenian evaporites studied from Upper Silezia (Poland), belong to the lower part of the NN6 zone.

The Sarmatian assemblages prove a high frequence of the species Calcidiscus leptoporus, Cyclicargolithus floridanus, Calcidiscus macintyrei, Coccolithus miopelagicus, Coccolithus pelagicus, Triquetrorhabdulus rugosus, Sphenolithus abies, Sphenolithus moriformis. Rarely specimens of Sphenolithus heteromorphus, the index species for NN5 Zone were remarked.

The assemblages also contain: Reticulofenestra pseudoumbilicus, Pontosphaera multipora, Syracosphaera histrica, Discoaster cf. musicus, Umbilicosphaera cf. jafari, Holodiscolithus macroporus.

The Pannonian deposits which contain representative mollusks and ostracods are very scarce in calcareous nannofossils (Tab. 1).

Table 1.

Representative calcareous nannofossils from Bistrita area (according to the classification of Young \& Bown, 1997).

\begin{tabular}{|c|c|c|c|c|}
\hline NANNOFOSSIL SPECIES & 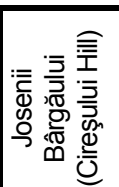 & 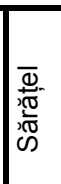 & 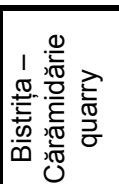 & $\begin{array}{l}0 \\
0 \\
0 \\
0 \\
0 \\
0 \\
0 \\
0 \\
0 \\
0 \\
0 \\
0\end{array}$ \\
\hline $\begin{array}{c}\text { CALCAREOUS NANNOPLANKTON: } \\
\text { HETEROCOCCOLITS } \\
\text { Family Helicosphaeraceae }\end{array}$ & & & & \\
\hline Helicosphaera carteri (WALLICH, 1877) KAMPTNER (1954) & $\mathrm{X}$ & & $\bar{X}$ & $\bar{X}$ \\
\hline Helicosphaera wallichii (LOHMAN, 1902) OKADA \& MCINTYRE (1997) & $\mathrm{X}$ & & & $\mathrm{X}$ \\
\hline
\end{tabular}




\begin{tabular}{|c|c|c|c|c|}
\hline Helicosphaera mediterranea (MUELLER, 1974) & & & $\mathrm{X}$ & \\
\hline Helicosphaera euphratis (MUELLER, 1974) & & & $\bar{X}$ & \\
\hline Helicosphaera walbersdorfensis (MUELLER, 1974) & & & $\mathrm{X}$ & \\
\hline \multicolumn{5}{|l|}{ Family Pontosphaeraceae } \\
\hline Pontosphaera multipora (KAMPTNER, 1948) ROTH (1970) & $\mathrm{X}$ & $\mathrm{X}$ & $\mathrm{X}$ & $\mathrm{X}$ \\
\hline \multicolumn{5}{|l|}{ Family Calciosoleniaceae } \\
\hline Calciosolenia murrayi DEFLANDRE IN DEFLANDRE \& FERT (1954) & & & $\mathrm{X}$ & \\
\hline \multicolumn{5}{|l|}{ Family Syracosphaeraceae } \\
\hline Syracosphaera histrica KAMPTNER (1941) & & $\mathrm{X}$ & & $\bar{X}$ \\
\hline \multicolumn{5}{|l|}{ Family Rhabdosphaeraceae } \\
\hline Rhabdosphaera pannonica BALDI-BEKE (1960) & $\mathrm{X}$ & & $\mathrm{X}$ & \\
\hline \multicolumn{5}{|l|}{ Family Noelaerhabdaceae } \\
\hline Cyclicargolithus floridanus (ROTH \& HAY in HAY et al., 1967) BUKRY (1971) & $\mathrm{X}$ & $\mathrm{X}$ & $\bar{X}$ & $\bar{X}$ \\
\hline Reticulofenestra pseudoumbilicus (GARTNER, 1967) GARTNER (1969) & $\mathrm{X}$ & $\mathrm{X}$ & $\mathrm{X}$ & $\mathrm{X}$ \\
\hline Reticulofenestra minuta ROTH (1970) & & & $\mathrm{X}$ & \\
\hline \multicolumn{5}{|l|}{ Family Coccolithaceae } \\
\hline Coccolithus miopelagicus BUKRY (1971) & $\mathrm{X}$ & $\mathrm{X}$ & $\mathrm{X}$ & $\bar{X}$ \\
\hline Coccolithus pelagicus (WALLICH, 1877) SCHILLER (1930) & $\mathrm{X}$ & $\mathrm{X}$ & $\mathrm{X}$ & $\mathrm{X}$ \\
\hline \multicolumn{5}{|l|}{ Family Calcidiscaceae } \\
\hline $\begin{array}{l}\text { Calcidiscus leptoporus (MURRAY \& BLACKMAN, 1898) LOEBLICH \& } \\
\text { TAPPAN (1978) }\end{array}$ & & & & $\bar{X}$ \\
\hline Umbilicosphaera jafari MÜLLER (1974) & & & $\mathrm{X}$ & $\mathrm{X}$ \\
\hline Umbilicosphaera rotula & $\mathrm{X}$ & & & \\
\hline \multicolumn{5}{|l|}{$\begin{array}{c}\text { NANNOLITHS } \\
\text { Family Braarudosphaeraceae }\end{array}$} \\
\hline $\begin{array}{l}\text { Braarudosphaera bigelowii (GRAN \& BRAARUD, 1935) DEFLANDRE } \\
\text { (1947) }\end{array}$ & & & $\mathrm{X}$ & \\
\hline \multicolumn{5}{|l|}{ Family Discoasteraceae } \\
\hline Discoaster musicus STRADNER (1959) & $\mathrm{X}$ & & $\mathrm{X}$ & $\mathrm{X}$ \\
\hline Discoaster cf. musicus STRADNER (1959) & $\mathrm{X}$ & & $\mathrm{X}$ & $\mathrm{X}$ \\
\hline Discoaster deflandrei BRAMLETTE \& RIEDEL (1954) & $\mathrm{X}$ & & $\mathrm{X}$ & \\
\hline Discoaster brouweri TAN (1927) emended BRAMLETTE \& RIEDEL (1954) & & & $\mathrm{X}$ & \\
\hline Discoaster variabilis MARTINI \& BRAMLETTE (1963) & $\mathrm{X}$ & & $\mathrm{X}$ & \\
\hline Discoaster exilis MARTINI \& BRAMLETTE (1963) & $\mathrm{X}$ & & $\mathrm{X}$ & \\
\hline \multicolumn{5}{|l|}{ Family Sphenolithaceae } \\
\hline Sphenolithus heteromorphus DEFLANDRE (1953) & $\mathrm{X}$ & $\mathrm{X}$ & $\mathrm{X}$ & \\
\hline $\begin{array}{l}\text { Sphenolithus moriformis (BRÖNNIMANN \& STRADNER, 1960) } \\
\text { BRAMLETTE \& WILCOXON (1967) }\end{array}$ & $\mathrm{X}$ & & & $\mathrm{X}$ \\
\hline Sphenolithus abies DEFLANDRE in DEFLANDRE \& FERT (1954) & $\mathrm{X}$ & $\mathrm{X}$ & $\mathrm{X}$ & $\mathrm{X}$ \\
\hline Sphenolithus neoabies BUKRY \& BRAMLETTE & $\mathrm{X}$ & & & \\
\hline \multicolumn{5}{|l|}{ Family Triquetrorhabdulaceae } \\
\hline Triquetrorhabdulus rugosus BRAMLETTE \& WILCOXON (1967) & & $\bar{X}$ & $\mathrm{X}$ & $\bar{X}$ \\
\hline \multicolumn{5}{|l|}{ CALCAREOUS DINOFLAGELLATES } \\
\hline Thoracosphaera heimii (LOHMANN 1919) Kamptner 1941 & $X$ & $\mathrm{X}$ & $\mathrm{X}$ & $\mathrm{X}$ \\
\hline Thoracosphaera sp. & $\mathrm{X}$ & $\mathrm{X}$ & $\mathrm{X}$ & $\mathrm{X}$ \\
\hline
\end{tabular}




\section{CONCLUSIONS}

In conclusion, in the Bistrița area, the calcareous nannofossils allow us to evidence the presence of the Middle Miocene deposits, belonging to Badenian (NN5 - NN6), Sarmatian (NN7 - NN9) and Pannonian (NN10 - NN11).

Only for the Badenian deposits the marker species from the standard zonations have been identified: Sphenolithus heteromorphus (NN5) and Discoaster exilis (NN6) (Martini's zonation, 1971).

The data concerning the calcareous nannofossils, based on the assemblage with Discoaster exilis, D. variabilis, Triquetrorhabdulus rugosus, Cyclicargolithus floridanus, a.o., allow us to attribute the analysed clays from the salt to Wieliczkian.

The extinction of Cyclicargolithus floridanus is considered to mark the limit between NN6/NN7 Zones.

The index species for NN5 - Sphenolithus heteromorphus was rarely noticed in the analysed samples, as well as the index species for NN6 - Discoaster exilis was observed in the analysed samples too. But the whole assemblage is scarce in calcareous nannofossils as compared to the abundance of nannofloras that generally characterize the Moravian (Early Badenian) (NN5 Zone - with Sphenolithus heteromorphus).

NN6 Zone - with Discoaster exilis is marked at the upper part by the last appearance of Cyclicargolithus floridanus. It is characteristic for Wieliczkian and Kossovian.

Generally, in Central Paratethys, the beginning of NN6 Zone can be correlated with the first appearance of Triquetrorhabdulus rugosus. The frequence of Cyclicargolithus floridanus is decreasing towards the upper part of the zone.

The studied deposits at the level of salt, can be considered to belong to the upper part of NN5 Zone (NN5b Subzone) and the lower part of NN6 Zone (NN6a Subzone), both corresponding to Middle Badenian (Wieliczkian).

The nannofossils assemblages of the Pannonian deposits, as well as those of the Sarmatian ones, are very scarce, and the marker species are lacking. Generally, they are attributed to NN7 - NN11 Zones.

\section{REFERENCES}

Bramlette, M. N., Wilcoxon, J. A., 1967, Middle Tertiary Calcareous Nannoplankton of the Cipero Section, Trinidad, W. I. Tulane Studies Geology, 5, p. 93 - 131.

Chintăuan, I., 1994, Stratigrafia şi paleontologia Neogenului din regiunea Bistrița-Budac.Teza de doctorat, 208 p., Cluj-Napoca.

Chira, C., 1999, Middle Miocene calcareous nannoplankton from the western Transylvanian Basin, Romania: Biostratigraphy, taxonomy and palaeoecology. Studia Univ. BabeşBolyai, Geol.-Geogr., XLIV, 2, p. 3 - 75, 6 figs., 2 tab., 7 pl., Cluj-Napoca.

Chira C., 2000, Nannoplancton calcaros şi moluşte miocene din Transilvania. Ed. Carpatica, 183 p., 21 figs., 8 tab., 20 pl., Cluj-Napoca.

Chira, 2001, The Badenian calcareous nannoplankton from Turda and Ocna Dej salt mines (Transylvanian Basin, Romania). Studia Univ. Babeş-Bolyai, Geol.-Geogr., XLVI, 2, p. 141 - 150, 1 fig., 1 tab., 2 pl., Cluj-Napoca.

Ciocîrdel, R., 1953, Contribuțiuni la cunoaşterea geologiei regiunii Bistrița - Reghin. D.S. Inst. Geol. Rom., XXXVI, 96 - 107, Bucureşti. 
Filipescu, S., 1996, Stratigraphy of the Neogene from the western border of the Transylvanian Basin. Studia Univ. Babeş-Bolyai, Geol.-Geogr., XLI, 2, p. 3 - 77, 16 figs., 5 tab., 6 pl., Cluj-Napoca.

Filipescu, S., 2001, Cenozoic lithostratigraphic units in Transylvania. In Field Trip Guide, $4^{\text {th }}$ Regional Meeting of IFAA (Bucur et al., Ed.), p. 75 - 92, Cluj-Napoca.

Fornaciari, E., Di Stefano, A., Rio, D., Negri, A., 1996, Middle Miocene quantitative calcareous nannofossil biostratigraphy in the Mediterranean region. Micropaleontology, 42, 1, p. 37 63 , tex-figs. 1 - 18, pl. $1-3$, appendix 1.

Fuchs, R., Stradner, H., 1977, Über Nannofossilien im Badenien (Mittelmiozän) der Zentralen Paratethys. Beitr. Paläont. Österr., 2, p. 1 - 58, 4. Abb., 2 Tab., 8 Taf., Wien.

Hauer, F., Stache, G., 1863: Geologie Siebenbürgens. 637 p., 10 pl., Wien.

Marinescu, F., Peltz, S., 1967, Harta geologică scara 1:200.000, 11. Bistrița. Inst. Geol., 30 p., Bucureşti.

Koch, A., 1900, Die Tertiärbildungen des Beckens der Siebenbürgischen Landesteile. II Neogene Abteilung, 370 p., 50 fig., 3 pl., Budapest.

Martini, E., Worsley, 1970, Standard Neogene calcareous nannoplankton zonation. Nature, 225, p. $289-290$.

Martini, E., 1971, Standard Tertiary and Quaternary Calcareous Nannoplankton Zonation. Proceedings of the II Planktonic Conference, Roma , 1970, A. Farinacci, ed., Ed. Tecnoscienza, p. 739 - 785, Rome.

Mărunțeanu, M., Chira, C., 1998, Marine middle Miocene calcareous nannoplankton: a comparative study of the Subcarpathians and Transylvanian Basin. Abstract. XVI. Carpatho-Balkan Congress, Vienna, 1998.

Mărunțeanu, M., Crihan, M., Chira, C., 2000, Badenian nannofossil zonation - the Carpathian area. Acta Palaeontologica Romaniae, 2, p. 261 - 267, Cluj-Napoca.

Mészaros, N., Nicorici, E., Filipescu, S., 1989, Le nannoplancton des dépots néogenes saliféres traversés par les forages executés aux environs de la ville Turda. Studia Univ. BabeşBolyai, Geol.-Geogr., XXXIV, 2, Cluj-Napoca.

Mészaros, N., 1991, Nannofossil Zones in the Paleogene and Miocene Deposits of the Transylvanian Basin. Proced. IV. INA Conf., Knihovnicka ZPN, 14 b, 2, p. 87 - 92, 3 fig., Prague.

Müller, C., 1974, Nannoplankton aus dem Mittel-Miozän von Walbersdorf (Burgenland). Senckenbergiana lethaea, 55 (1/5), p. 389 - 405, 4 Taf., Frankfurt am Main.

Pătruț, I., 1952, Geologia regiunii Beclean (jud. Someş). D.S. Inst. Geol. Rom., XXXVI, 96 - 107, Bucureşti.

Perch-Nielsen, K., 1985, Cenozoic calcareous nannoplankton. In: Plankton Stratigraphy, (Bolli et al. eds.) , Cambridge Univ. Press, p. $427-554$.

Peryt, D., 1997, Calcareous Nannoplankton Stratigraphy of the Middle Miocene in the Gliwice Area (Upper Silesia, Poland). Bulletin of the Polish Acad. of Sci. Earth Sci., 45, 2 - 4, p. 119 - 131, 4 figs., 3 pls., Warszawa.

Petrescu, I., Chintăuan, I,. 1987, Plante fosile din Pannonianul regiunii Budacu de Sus-Cuşma (Bistrița-Năsăud), manuscris.

Popescu, G., 1970, Planktonic Foraminiferal Zonation in the Dej Tuff Complex. Rev. Roum. Géol., Géoph., Géogr., ser. Geol., 14/2, p. 189 - 203, Bucureşti.

Popescu, G., 1972, Biostratigrafia depozitelor oligo-miocene de la sud de Preluca pe bază de foraminifere. D. S. Inst. Geol., LVIII, 3, p. 105 - 127, Bucureşti. 
Popescu, G., Gheța, N., 1984, Comparative Evolution of the Marine Middle Miocene Calcareous Microfossils from the Carpathian and Pannonian Areas. D. S. LXIX/3, p. $125-133$, Bucureşti.

Rögl, F., Müller, C., 1976, Das Mittelmiozän und die Baden/Sarmat Grenze in Walbersdorf (Burgenland). Ann. Naturhist. Mus. Wien, 80, p. 221 - 232, 1 Abb., 2 Tab., Wien.

Theodoridis, S., 1984, Calcareous Nannofossil Biozonation of the Miocene and Revision of the Helicoliths and Discoasters. Utrecht Micropal. Bull., 32, p. 3 - 271, 66 figs., A - E text figs.,37 pl., Utrecht.

Vulc, A.-M., 2002: Studiul nannofosilelor calcaroase din regiunea Beclean-Bistrița. Lucr. diplom., 45 p., 2 pls., Cluj-Napoca.

Vulc, A.-M., 2003: Nannofosilele calcaroase miocene din regiunea Bistriței. Lucr. disert., 24 p., 5 pls., Cluj-Napoca.

Young, J., R., Bown, P. R., 1997, Cenozoic calcareous nannoplankton classification. Journal of Nannoplankton Research, 19, 1, p. $15-47$.

Young, J., R., 1998, Neogene. in Calcareous Nannofossil Biostratigraphy. In Bown, P. R. (Ed.), Chapman \& Hall, 309 p., London.

Plate I, Fig. (x 2.000):

1a, $1 \mathrm{~b}$ - Sphenolithus heteromorphus Deflandre. 1a - N+; 1b - N+; Budacu de Sus.

2a, 2b - Cyclicargolithus floridanus (Roth \& Hay) Bukry. 2a - NII; 2b-N+; Josenii Bârgăului Cireşului Hill.

3 - Sphenolithus abies Deflandre. N+; Josenii Bârgăului - Cireşului Hill.

4 - Sphenolithus neoabies, Coccolithus pelagicus (Bukry \& Bramlette) Wallich, Schiller. N+; Josenii Bârgăului - Cireşului Hill.

5 - Umbilicosphaera rotula Müller. NII;

6a, 6b - Coccolithus miopelagicus Bukry. 6a - NII; 6b - N+; Josenii Bârgăului -Cireşului Hill.

$7 \mathrm{a}, 7 \mathrm{~b}$ - Coccolithus pelagicus (Wallich) Schiller. Coccolithus miopelagicus Bukry. 7a - NII; $7 \mathrm{~b}-\mathrm{N}+$; Budacu de Sus.

Plate II Fig. (x 2.000):

1, 2, 3 - Discoaster variabilis Martini \& Bramlette. NII; 1, 2 - Josenii Bârgăului Cireşului Hill; 3 - Budacu de Sus.

4, 5 - Discoaster musicus Stradner. NII; 4 - Josenii Bârgăului - Cireşului Hill; 5 - Budacu de Sus.

6, 7 - Discoaster exilis Martini \& Bramlette. NII; Budacu de Sus.

8, 9, 10 - Discoaster cf. brouweri (Bramlette \& Riedel) Tan. NII; 8 - Bistrița - Cărămidărie quarry; 9, 10 - Budacu de Sus.

11, 12 - Discoaster deflandrei Bramlette \& Riedel. NII; 11 - Josenii Bârgăului -Cireşului Hill; 12 - Bistrița - Cărămidărie quarry. 
Plate III Fig. (x 2.000):

1a, $1 \mathrm{~b}$ - Calciosolenia murray Deflandre in Deflandre \& Fert.. 1a - NII; 1b - N+; Bistrița Cărămidărie quarry.

2a, 2b - Rhabdosphaera pannonica Baldi-Beke. 2a - NII; 2b - N+; Josenii Bârgăului Cireşului Hill.

3a, 3b - Rhabdosphaera pannonica Baldi-Beke. 3a - NII; 3b - N+; Bistrița - Cărămidărie quarry.

4a, 4b - Syracosphaera cf. hystrica Kamptner. 4a - NII; 4b - N+; Sărățel.

5 - Reticulofenestra pseudoumbilicus Gartner. N+; Josenii Bârgăului - Cireşului Hill.

6a, 6b, 7 - Calcidiscus leptoporus (Murray \& Blackman) Loeblich \& Tappan. 6a - NII; 6b - N+; Budacu de Sus. 7 - N+; Bistrița - Cărămidărie quarry.

Plate IV Fig. (x 2.000):

1a, 1b - Helicosphaera carteri Wallich, Kamptner. 1a - NII; 1b - N+; Josenii Bârgăului Cireşului Hill.

2a, 2b - Helicosphaera wallichii Lohmann (Okada \& Mclntyre). 2a - NII; 2b - N+; Josenii Bârgăului - Cireşului Hill.

3a, 3b - Braarudosphaera bigelowii (Gran \& Braarud) Deflandre. 3a - NII; 3b - N+; Bistrița - Cărămidărie quarry.

4 - Umbilicospahera jafari Müller, Coccolithus pelagicus Wallich, Schiller. N+; Budacu de Sus.

5 - Coccolithus pelagicus Wallich, Schiller, Coccolithus miopelagicus Bukry. N+; Budacu de Sus.

6a, 6b - Thoracosphaera heimii Lohmann, Kamptner. 6a - NII; 6b - N+; Josenii Bârgăului.

7 - Thoracospahera heimii Lohmann, Kamptner. N+; Bistrița - Cărămidărie quarry. 
THE MIOCENE CALCAREOUS NANNOFOSSILS FROM BISTRIȚA AREA (TRANSYLVANIA, ROMANIA)

Plate I
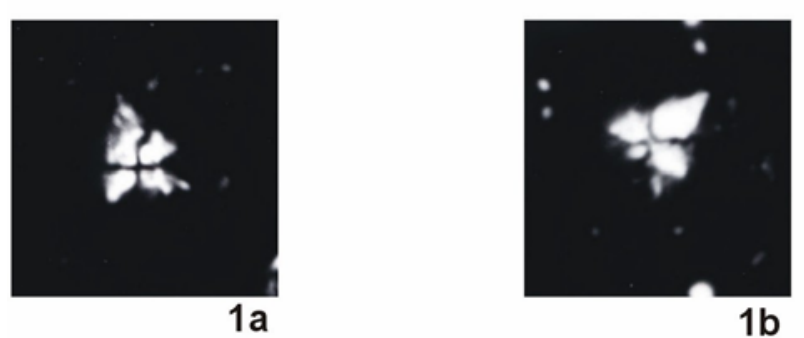

$1 b$
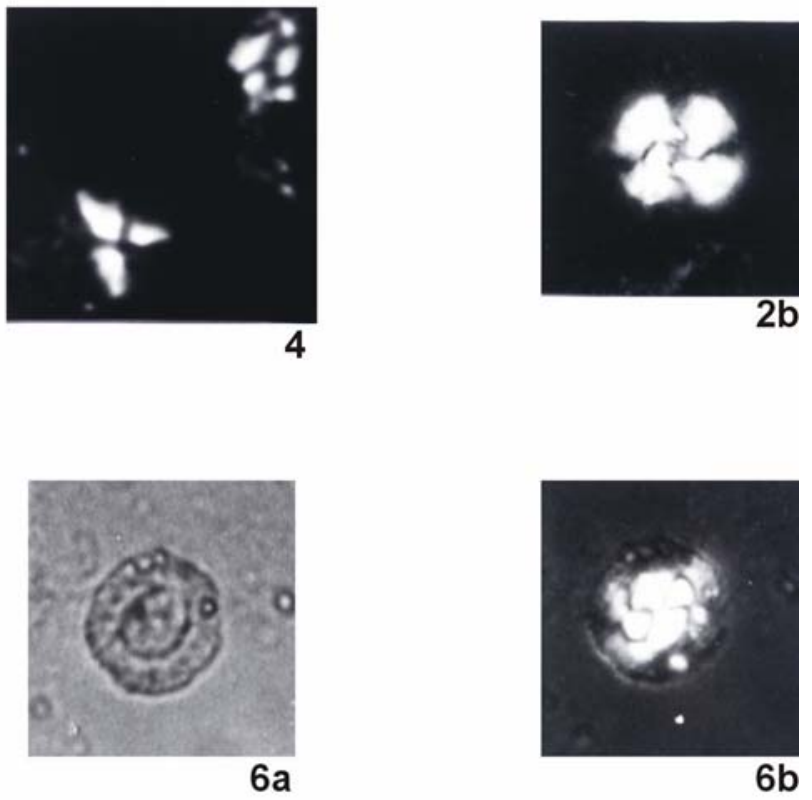
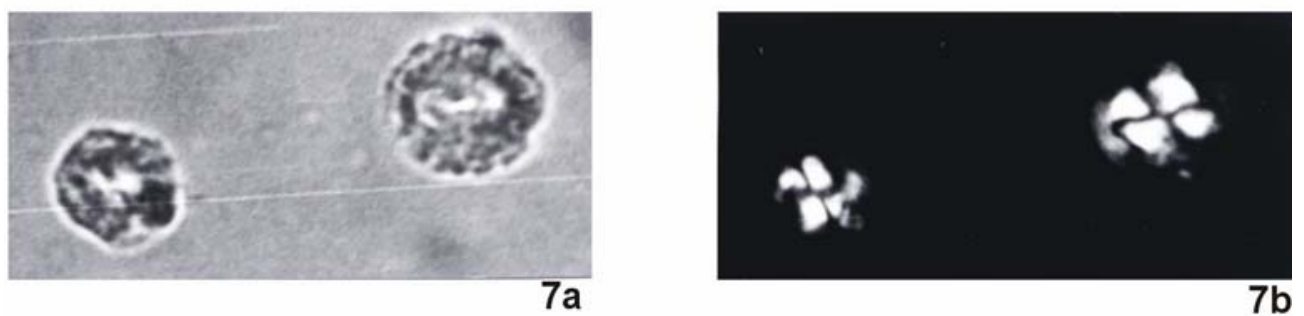


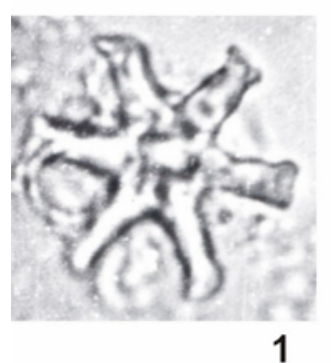

Plate II
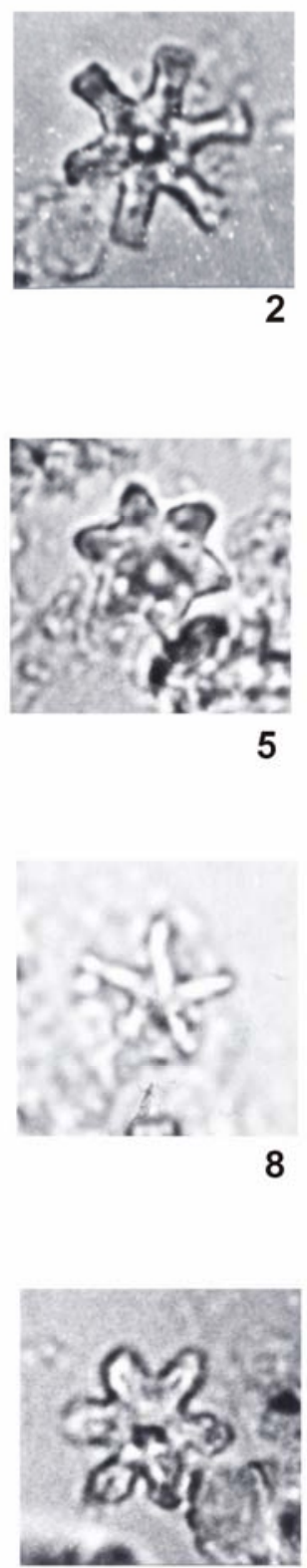

11
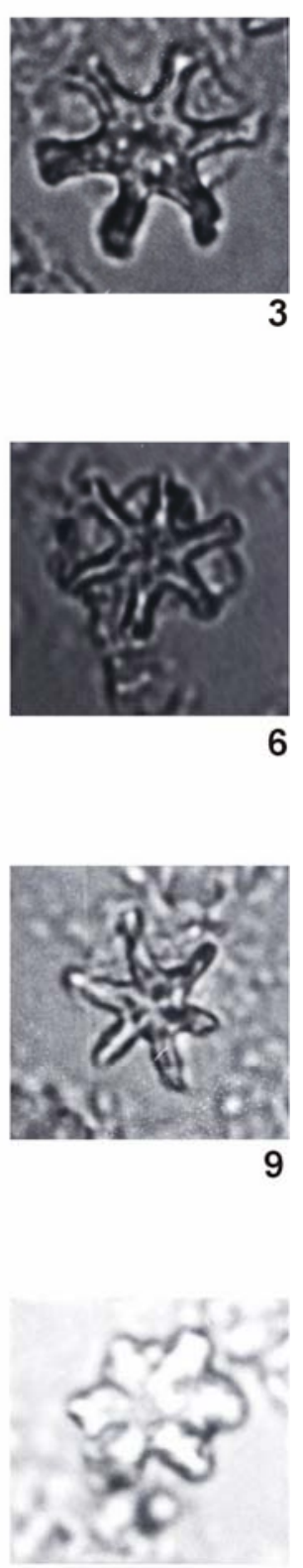

12 
THE MIOCENE CALCAREOUS NANNOFOSSILS FROM BISTRIȚA AREA (TRANSYLVANIA, ROMANIA)

\section{Plate III}
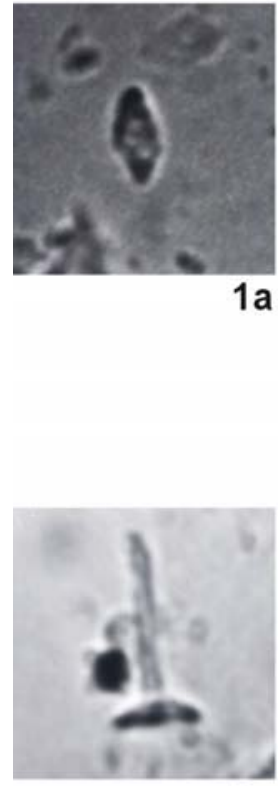

3a
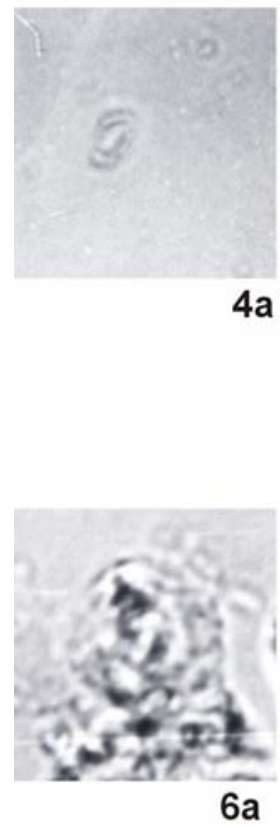

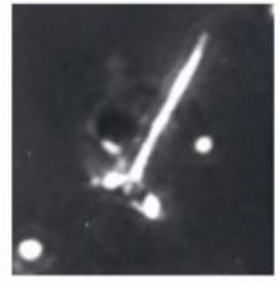

$3 b$
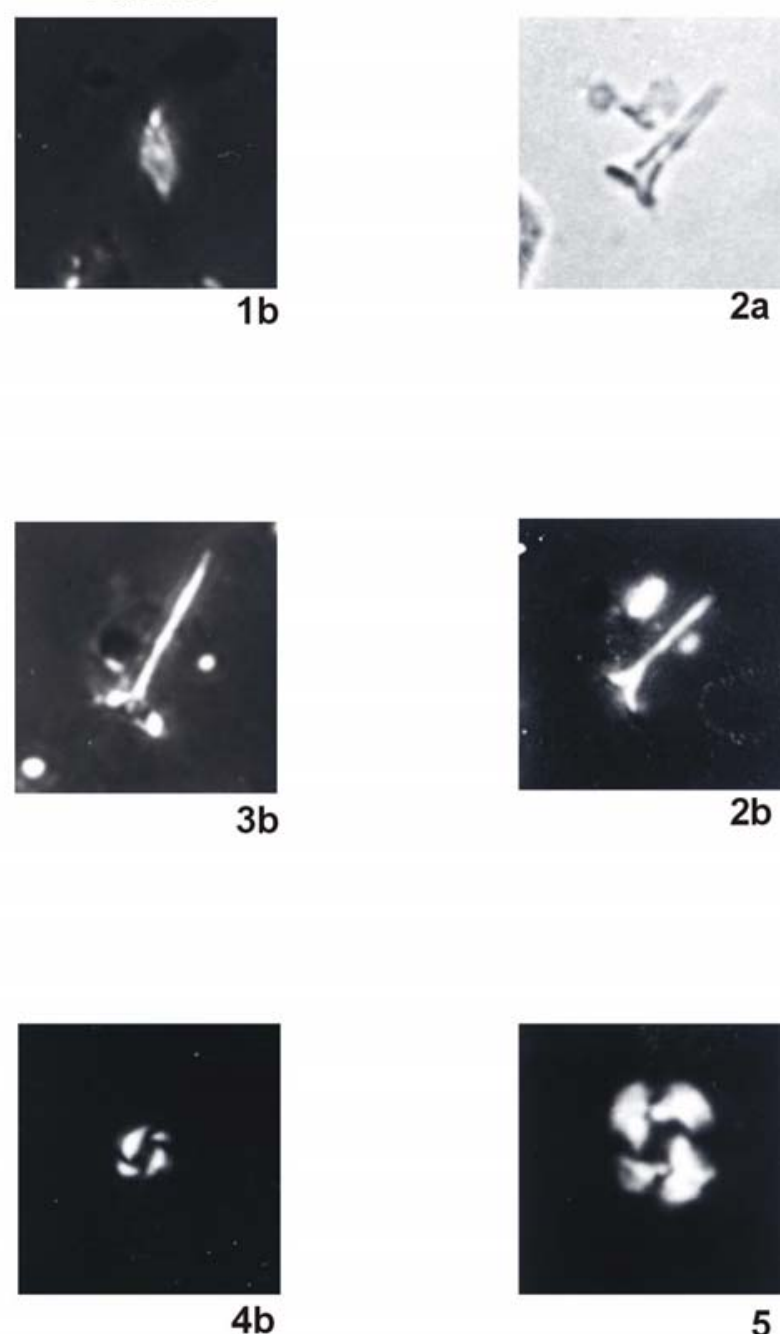

$2 a$

b
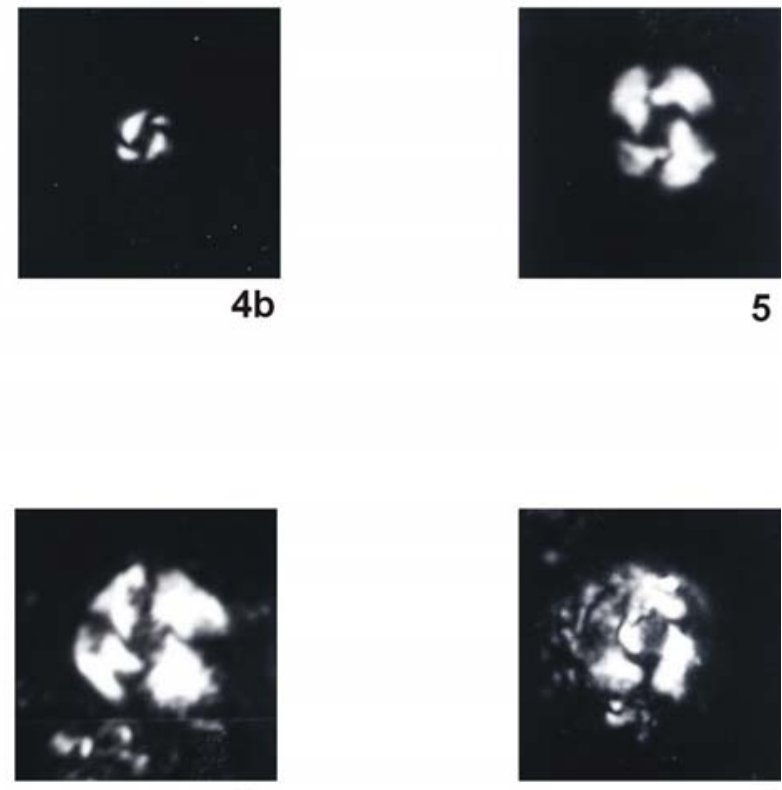

$6 b$

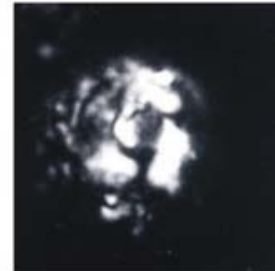

7
79 
CARMEN CHIRA, ANA-MARIA VULC
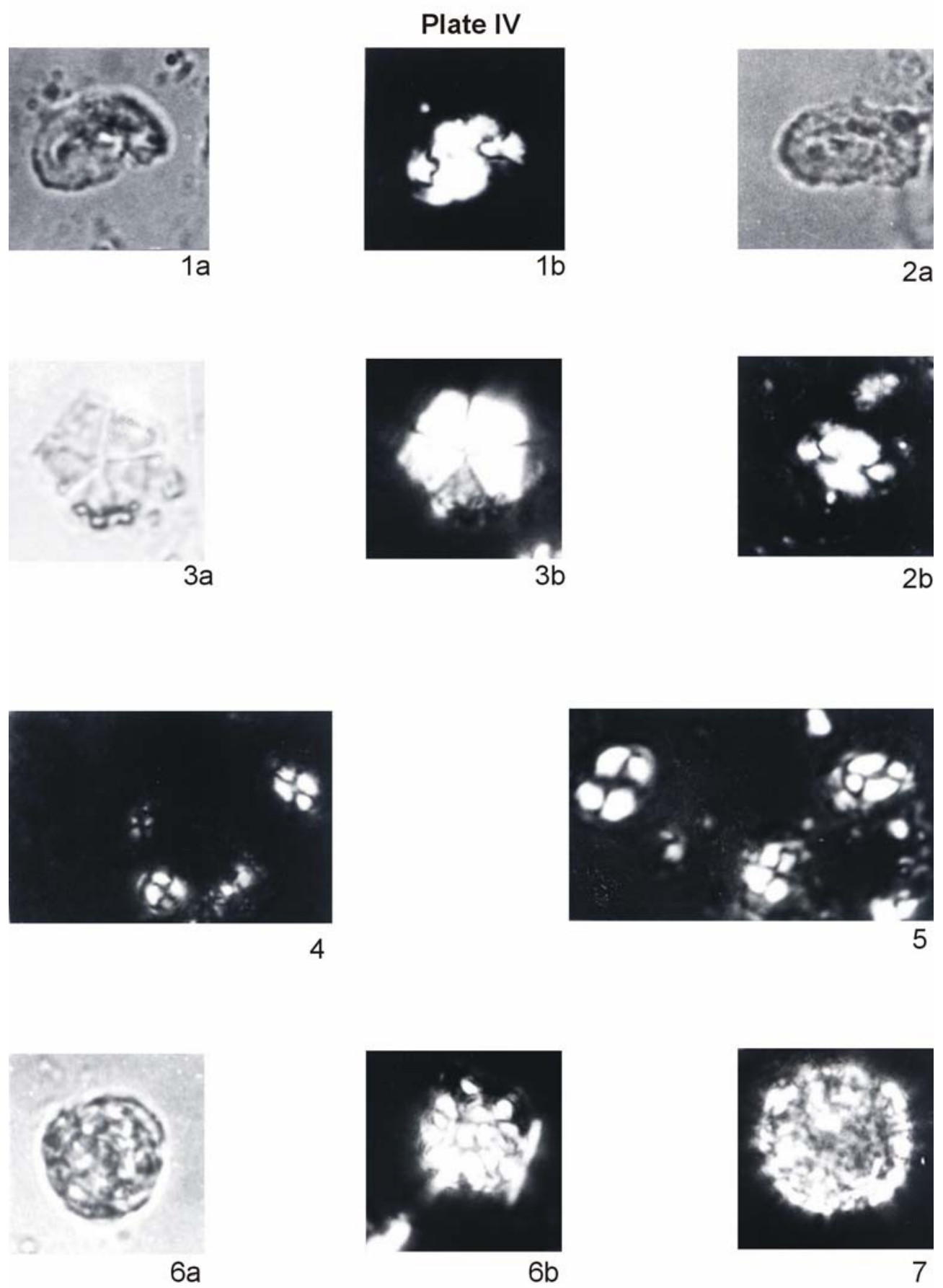